\title{
BRIEF REMARKS ON PRESIDENT R.T. ERDOGAN AND HIS ALLIES' METHODICAL USE OF LOGICAL FALLACIES
}

\author{
C. Melakopides \\ University of Cyprus \\ CY-1678, Nicosia, Cyprus, 20537
}

\begin{abstract}
This article has several aims. First, it is focused on revealing the disconcerting recent policies of President of Turkey R.T. Erdogan and his associates towards Greece and the Republic of Cyprus. These policies are characterized by aggressiveness and bellicosity, constituting a paradigm case of Turkey's broader geopolitical ambitions. Second, an attempt is made to account for R.T. Erdogan's probable political intentions and geopolitical ambitions via a number of explanatory hypotheses rationalizing their "incomprehensible" nature. And third, the article will determine the principal methods and means used in the foreign policy decision-making of Erdogan's regime, and will expand on his skillful employment of logical fallacies that have remained undetected in Erdogan-related bibliography.
\end{abstract}

Key words: R.T. Erdogan, Turkey, foreign policy, Republic of Cyprus, geopolitics, political narrative

\section{INTRODUCTION}

Recep Tayyip Erdogan's bold political and geopolitical intentions and actions have been attracting ongoing international interest. This interest has lately been intensified, especially during his long campaign for the June 2018 presidential and parliamentary elections. President Erdogan's ability to inspire and fascinate his audiences and nearly half the Turkish electorate co-exists with his uncanny ability to alienate the other half of his people and to infuriate countless states, their leaders, and important international organizations.

Greece and the Republic of Cyprus are the two states that remain less than fascinated by Erdogan and his policies. The Greeks of Cyprus are still suffering under the illegal and immoral occupation of 37 percent of their country since Turkey's invasion in 1974. The Greeks of Greece have long been outraged: Turkey's president has opted for aggressive rhetoric and bellicose actions, both in the Aegean Sea and in Cyprus' Exclusive Economic Zone (EEZ), thereby combating the Greeks' sustained efforts to cultivate harmonious relations.

In fact, for quite some time, Athens has been striving to handle any bilateral Greek-Turkish problems or disputes by appealing to International Law, active cooperation in "low politics", and cultivating authentic friendship with the Turkish people. A series of Greek prime ministers and foreign ministers, including Kostas Karamanlis, George Papandreou, Alexis Tsipras and Nikos Kotzias, have been at pains to promote mutual trust, mutual benefits and amicable neighbourly relations. However, it is hardly surprising that when confronted by Erdogan's escalating toxic responses, 92.5 percent 
of Greeks confirmed in a recent poll that they perceive Turkey as their country's greatest threat [7]. Five weeks later, a new research by "Public Issue" for Athens daily, Naftemboriki, revealed that " 87 percent believe that Greece faces its biggest foreign policy obstacle with Turkey, with 79 percent saying Turkey is a threat for the country" [10].

This essay will indicate the grounds for the Hellenic disappointment and anger; it will sketch some of President Erdogan's favourite methods and means in his foreign policy decision-making; and it will analyze his and his allies' propensity to use logical fallacies to serve their goals.

\section{ERDOGAN'S CONTROVERSIAL POLICIES AND HELLENIC EXPLANATORY HYPOTHESES}

Various hypotheses are being constantly produced to explain Erdogan's antiHellenic fixation. Some are inclined to blame his broader geopolitical ambitions, given his "megalomaniacal" declarations about the "Great Turkey" and his statements regarding "the borders of his heart" [9]. Others concentrate on his particular anti-Greece and anti-Cyprus policies and, therefore, add supplementary explanations to the "megalomaniac" hypothesis. Before addressing them, however, it is important to establish Erdogan's and his associates' recent anti-Hellenic behaviour.

To illustrate Erdogan's blatant conduct aiming to directly threaten and intimidate Greece and Cyprus, the following three examples should suffice: first, his insistence in Athens, in December 2017, that the 1923 multilateral Lausanne Treaty - which fixed the two countries' borders — should be "updated"; second, his naked threats against numerous Greek Aegean islands that Ankara has decided to label "Turkish" by fiat; and third, ad nauseam repetition that Ankara "will not tolerate unilateral actions" by the (legitimate) Cyprus government in the Cypriot Exclusive Economic Zone (EEZ). Concurrently, Erdogan made the following macabre declaration in early 2018 [8]:

Certainly we will build a great and dynamic future for Turkey, and for this we will sacrifice our life and will take the life of others when needed.

Meanwhile, Erdogan's close advisor, Yigit Bulut, after expressing his (surrealistic) "certainty" that Washington plans to make Greece attack Turkey, asserted that since Greece "is no match for Turkey's might", it would be "like a fly picking a fight with a giant" [5]. Moreover, regarding the Greek Imia islets that Turkey hopes to usurp, Bulut stated last January [5]:

We will break the arms and legs of any officers, of the Prime Minister, or of any minister, who dares to step onto Imia in the Aegean.

Similarly, when a handful of isolated fascists burned a Turkish flag in Athens last March, Mustafa Deztiji, president of the extreme-right BBP — Erdogan's expected ally in Turkey's forthcoming presidential election — proclaimed:

The Turkish flag one day will fly again in Athens [4].

Univocal hostile actions include the daily violation of Greek airspace in the Aegean and Athens FIR by armed Turkish military jets, demonstrating Ankara's expansionist designs, that disregard risking human lives; the endless flights by Turkish military jets 
over Greek islands, often a few hundred meters above the terrified inhabitants; the constant issue of illegal NAVTEX within the Republic of Cyprus' EEZ, aiming to disrupt Nicosia's hydrocarbon program; the "abortion" of gas drilling by SAIPEM 12000 in Bloc 3 of the EEZ in March 2018 by the Turkish Navy, violating Nicosia's contract with the Italian company ENI; the February 2018 deliberate crash of a Turkish coast guard vessel into a Greek patrol boat off Imia, ruthlessly threatening Greek sailors' lives; and the early March 2018 theatrical arrest of two Greek military employees who inadvertently crossed the northern Greek-Turkish border in miserable weather conditions. In June 2018, the two still remained hostages to help implement Ankara's transparent blackmail: the Erdogan regime has openly insinuated that the two Greeks should be "exchanged" for eight Turkish officers who sought asylum in Greece after the July 2016 attempted coup in Turkey.

In view of such mind-boggling behavior, Greek and Greek Cypriot analysts and opinion-makers keep airing explanatory hypotheses with particular "Greek content". Inter alia, they argue that Erdogan's verbal and non-verbal actions, while certainly prompted by his passionate pursuit of electoral victory in June 2018, primarily target the two countries because of their assumed inferior military strength; that Greece and Cyprus have encouraged his aggressiveness by their traditional option for appeasement, and that their illusion that "Europeanization" would tame Turkey's bellicose circles; that Turkey's threatening of both countries in these ways — including gunboat diplomacy — will either lead to their "Finlandization" or force them to "negotiate" under the barrel of the gun; and that, given apparently impressive hydrocarbon deposits in Cyprus' EEZ, Turkey feels it must usurp them through power politics and under false pretenses.

\section{ERDOGAN'S FOREIGN POLICY METHODS CONDEMNED}

The intimations of Erdogan's Geopolitical Theatre of the Absurd, concisely described above, have hinted at some of Ankara's favorite methods and means: threats to use force, bullying, open blackmail, actual use of military force, intimidation, offensive verbal attacks, demands for "updating" international treaties, and "megalomaniacal" declarations that include both concrete and ambiguous threats. These methods and means are currently being noted by the international community. Most remarkable were the Conclusions of the European Council of 22 March 2018, which included the following [2]:

12. The European Council strongly condemns Turkey's illegal actions in the Eastern Mediterranean and the Aegean and underlines its full solidarity with Cyprus and Greece. 13. Recalling its Conclusions of October 2014 and the Declaration of 21 September 2005, the European Council urgently calls on Turkey to cease these actions and respect the sovereign rights of Cyprus to explore and exploit its natural resources in accordance with EU and International law. 14. In this context, it recalls Turkey's obligation to respect International Law and good neighborly relations, and normalize relations with all EU Member States including the Republic of Cyprus.

Needless to say, Greeks and Greek Cypriots were relieved that, at long last, the European Union reacted to Ankara's belief that it can violate international legal norms 
and ethical values with impunity. Progressively, various capitals and other institutions are alerted to Erdogan's arrogance and bellicosity, fearing serious threats to regional peace and international security.

On the other hand, what we are still missing is an academic investigation of Erdogan's repertoire of controversial methods, means and ruses used in his foreign-policy decision-making. The further discussion will clarify his strategy by concentrating primarily on the use of logical fallacies.

Before turning, however, to their examination, I wish to submit a note on another, rarely noticed, distinct Turkish "methodological" proclivity. This is Erdogan's and Ankara's skillful use of "strepsodikia" - Greek for logical sophisms — that is, the tendency to twist and distort historical, legal, political, and geopolitical arguments and facts to serve populist and chauvinistic goals [11]. For instance, Turkey has been using strepsodikia to deepen international confusion on the real nature of the Cyprus problem. Erdogan and his ministers resort to conceptual distortion and legalistic manipulation, presenting Turkey's illegal and immoral policies as paradigms of morality and legality and claiming to represent "the equal rights" of the "Turkish Republic of Northern Cyprus". In reality, this occupied territory, according to the European Court of Human Rights, is a "puppet state" and illegal appendix to the Republic of Turkey, which has been forcefully condemned by UN Security Council Resolutions 541(1983) and 550 (1984). Hence, no country in the world has recognized it with the exception of Turkey.

\section{INTENTIONAL USE OF LOGICAL FALLACIES}

All the above mentioned "practices" demonstrate Ankara's entrenched decision to use any methods and means, even immoral and illegal, to achieve its expanding political and international geopolitical ambitions ${ }^{1}$. Our discussion will now focus on a central dimension of Erdogan's methodological repertoire that has escaped "academic" attention: namely the employment of logical fallacies which constitute serious violations of the universal Rules of Logic.

A noteworthy recent case involved Turkey's EU Affairs Minister Omer Celik. On June 6, 2018, he "slammed" a Netherlands mayor for granting permission to roast pork in front of a mosque during iftar (the fast-breaking meal): ${ }^{2}$

"On Thursday, at the time of the breaking of Ramadan fast, members of this fascist organization will hold a barbeque party in front of Rotterdam's Laleli Mosque of Islamitische Stichting Nederland and they will roast pigs on spits", Celik tweeted.

Omer Celik is known to international media as a notorious "slammer" of individuals, states and institutions. In addition, he usually complains, protests, or expresses surprise at the foolishness and/or insanity of those he slams. Such acts, of course, commit the logical fallacy Ad Hominem, or attack against the person (as opposed to his/her ideas).

1 For Turkey's unbounded, even "global" ambitions, see [3]. Intriguingly, this "megalomaniacal" book has evaded translation in major languages.

2 See [14]. "Slamming" is the term used by Hurriyet Daily News to describe Ankara's continuous rhetorical attacks against, inter alia, the EU, the US, the UN, Germany, France, Greece, Israel, and Cyprus. 
For certain, the act in front of the Dutch mosque involved a form of provocation, since eating pork is forbidden for Muslims. But this time, Celik did not simply complain. His passionate intervention involved primarily pontificating and hectoring.

Celik said this is the most immoral attempt ever in the history of hate crimes. "Granting legal permission to such an immoral activity is also another deficiency of morality", he added [14].

Hectoring and pontificating, of course, are nothing but begging the question, one of the most common logical fallacies ${ }^{3}$. Minister Celik's moralistic diatribe, however, continued on a pseudo-poetic level:

"Celik also said Turks and other Muslims in Rotterdam will lay flowers around the mosque and 'erect a wall of love with flowers against the odor of hate,". "Muslims will teach a humanity lesson against this policy of hatred. Thus, they will remind everyone of the respect to mosques, churches and synagogues", he said.

The sad truth, however, is that the last statement has "the odor" of a ludicrous lie. Respect for churches and synagogues by the Erdogan regime has widely been questioned, if only because the most emblematic Church of Orthodox Christianity, Aghia Sophia, keeps being violated in various ways over the centuries. The fact that it operates as a Museum from 1935 to this day has not prevented chauvinists and religious fanatics from committing frequent politico-religious offences. Equally profound, and on a larger scale, is the utter violation of respect for churches in Turkey-occupied Cyprus, where churches have either been demolished or transformed into barns or bars.

In any event, Omer Celik's last statement constitutes a glowing paradigm of non sequitur; that is, the fallacy "it does not follow". For few people could believe that "erecting a wall of flowers" around a mosque in Rotterdam would necessarily become associated either with a broader call for respect for synagogues and churches or, for that matter, with mosques in general.

But Celik's assertion, typical of the Erdogan regime's propagandistic repertoire, exhibits additional fallacies. The first is the claim that "this is the most immoral attempt ever in the history of hate crimes". However, any definition of "hate crime" essentially contains violence, which is completely irrelevant in the Rotterdam case. Moreover, to call it "the most immoral attempt in the history of hate crimes" is insulting to all the victims of true hate crimes, from victims of the Ku Klux Klan, to the Holocaust, to today's anti-Semitic violence and caste-related violence in India. Therefore, Celik's fake judgement is manifestly fraught with additional logical errors.

Moreover, it is revolting to see an Ankara Minister appeal to "the history of hate crimes", when his country has a long background of exterminating Kurds in Southeast Turkey and, more recently, in Syria's Afrin, the differentia specifica in both cases being the Turkish Army's emphatic use of violence. Analogously, the Erdogan regime has no business to talk of "morality" and "policies of hatred" when Turkey has been occupying

${ }^{3}$ Begging the Question, we recall, occurs when someone assumes the truth of a conclusion instead of providing grounds to support it. 
over one-third of Cyprus since 1974 and is simultaneously engaged in the unending anti-Hellenic policies of intimidation mentioned above. In fact, all these policies are unquestionable examples of hate crimes; manifestly racist, and pursued through an orchestrated synthesis of blackmail, threats, bullying and direct aggression.

Other fallacies also include ones committed domestically by the Erdogan regime, the most widespread being the Ad Hominem. The attacks against thousands of people, who have been imprisoned or laid off after the attempted coup of July 15, 2016, without any proof of culpability - unless one counts subjective definitions of an authoritarian regime - are paradigm cases of Ad Hominem attacks on a massive scale.

All the above-mentioned crises, resulting from Erdogan's policies, force Ankara to employ fallacies in order to achieve misinformation via manipulation of historical and legal facts. Given that such acts are clear examples of strepsodikia, a new kind of fallacious synthesis has been brought about by the Erdogan regime. And since among Turkey's main goals is its exculpation, the most obvious fallacies employed in all these cases are, again, Begging the Question and the fallacies of Inconsistency and Equivocation ${ }^{4}$.

\section{ERDOGAN'S ALLY, MR DEVLET BAHCELI}

Erdogan's supporter, extreme-right-winger and leader of the Nationalist Movement Party (MHP), Devlet Bahceli, recently distinguished himself by initiating entirely uncivilized attacks against the Greeks. Preparing for the June 2018 elections, he misrepresented the Greek nation with fallacious rhetoric, the essence of which was selling banalities to the public. Bahceli's favourite facile fallacy is that of Red Herring. This fallacy is committed when a statement is used to divert attention from the real issue by switching the focus to an issue of little or only tangential relevance to the real issue. Thus, during his campaign, Bahceli threatened, at least twice, to send the Greeks "to find their ancestors" at the bottom of the Aegean Sea.

More specifically, Bahceli, the "stone-faced" leader of the "Grey Wolves", declared:

The Greek government, which plays games with the islands of the Aegean Sea, should learn its limits and should not forget what its ancestors went through when they were thrown to the bottom of the sea. The same will happen again. God willing, the willingness to render the Aegean once again the graveyard of the desires of the Greeks is still alive. And it will continue to be (alive) until the end"

Here, the "red herring" fallacy consists in bringing up the Smyrna tragedy, which is done for two reasons: first, in order to deeply traumatize the Greeks, because this is part of their "Asia Minor Catastrophe"; and second, to hide the absence of any explanation for the "Greek games with the Aegean islands". Therefore, Bahceli here is also "Begging the Question", for the truth regarding the Greek Aegean Islands is solidly established

${ }^{4}$ For a useful list and explication of main Fallacies, see, for instance [6].

${ }^{5}$ See [1] Bahceli obviously intended to remind the Greeks of the misery that ensued from the burning of Smyrna and their desperate attempts to reach boats and ships in order to cross the Aegean towards Greece. 
by International Law, and this was precisely the ground for the European Council's "strong condemnation" of Turkey's "illegal actions in the Aegean", as we have seen.

In addition, "Bahceli's delirium" constitutes a paradigm of irrationality, since the quotation above contains two additional fallacies: first, the fallacy of "False Analogy"; and second, the "Confusion of a Necessary with a Sufficient Condition". In the first of them, the analogy is false because the Greeks are presently fully aware of the Erdogan regime's bellicose mood, cultivated for months for any of the aforementioned reasons. Therefore, Greece has been fortifying its deterrence "just in case". As for the second fallacy, the Turkish willingness to "render the Aegean again a Greek graveyard" is by no means sufficient for the alleged goal or intention, as stated by the leader of the "Grey Wolves".

The above cited speech earned Bahceli a triumphant standing ovation with the audience, demonstrating the effects of the sustained anti-Hellenic brain-washing of the Turkish people, especially during the first six months of 2018. This reprehensible statement followed his earlier appalling declaration. Upon the release of a short video by his party, where, along with Turkey, the Republic of Cyprus stands covered with the Turkish flag, and after the angry protests in Cyprus and Greece that followed the release, Bahceli expressed his "surprise" [1]:

Why? Because it shows Cyprus as Turkish territory. I will ask these silly and thickheaded persons: 'what were we supposed to do?', 'how were we supposed to show (Cyprus)?' I declare it and emphasize it. "Cyprus is Turkish. It is Turkish and Turkish it will remain".

Having said enough about Bahceli's delirium, one can only add, epigrammatically, that the last statement is a monument to fallacious thinking and banal politicking. Once again, the extreme right-winger has committed a Grand Non Sequitur, for not only is Cyprus far from being "Turkish", but the Republic of Cyprus is an independent state recognized by the entire world on the basis of International Law and, according to European Law, the entire Republic is a Member of the European Union, including the occupied territory [12. P. 14-30].

Inevitably, one is tempted to ask the following question: if Recep Tayyip Erdogan's presidential ally is such a master of logical fallacies or, otherwise put, a proponent of passionate irrationality, what does this imply about Erdogan and his judgment to have embraced such an ally?

\section{BACK TO PRESIDENT ERDOGAN}

Before a final look at the Turkish president himself, let me report, first, that Greek Cypriot and Greek media every day, and the Television channels every evening, are flooded with Erdogan's own performances and related news that keep boggling the Hellenic minds. One can say with certainty that there is practically universal agreement about the "irrationality" of Erdogan's behaviour in terms of both ordinary perception and as interpreted by the Theory of International Relations [11]. In all these terms, Erdogan's recent behaviour constitutes the apotheosis of Hubris. What is not yet agreed 
upon is whether Nemesis is not far behind. But the fact that Erdogan's aggressiveness, bellicosity, his penchant for threats and blackmail, and his tireless efforts to offend and/or intimidate Cyprus, Greece, Israel, the entire Eastern Mediterranean, and beyond, is gradually being perceived as bringing his Nemesis closer every day.

The latest crisis, occurring mid-June 2018, erupted because of Austria's decision to close down a number of mosques and investigate the residence permits of 40 imams associated with these mosques [15]. After the reaction by Erdogan's spokesman, Ibrahim Kalin, that Vienna's decision reflects "the Islamophobic, racist and discriminatory wave" in Austria, the Turkish president proceeded to "slam" Austrian Chancellor, Sebastian Kurz:

"I'm making a call to the Austrian prime minister: You are still young and you need experience. Your inexperienced behaviour could cost you heavily", Erdogan said... repeating his earlier warning that Austria's decision "could start a crusader-crescent war" [15].

Erdogan then added a few perplexing sentences that culminated in an obscure threat:

"I am also making this call to the whole West, particularly to Germany: Straighten out your man. Otherwise the situation may get out of hand. We have some steps to be taken in accordance with our arguments", he said [15].

The Ad Hominem slamming of the Austrian leader — by fastening on his age and ignoring his rights as elected Chancellor — is evident enough. Erdogan, however, is rarely satisfied with a mere "slamming", which is why he immediately added an ambiguous threat aiming at intimidation by means of political-psychological bullying. ("Your inexperienced behaviour could cost you heavily".) Eventually, matters got completely out of hand: the "warning" that Austria's decision "could start a crusadercrescent war", if taken in association with Erdogan's political-Islamic fixation, his bellicose reactions to any criticism, and his passion for hectoring and pontification, offers an explosive combination, from which one cannot exclude toxic political and geo-political implications. Thus, from yet another logical fallacy he moved to personal bullying and collective threats, just before the most ambiguous - and therefore the most alarming — threat of all: "We have some steps to be taken in accordance with our arguments".

The last sentence comes laden with intentional ambiguity. Moreover, in combination with the "Cross versus Crescent war" threat, it commits the Slippery Slope fallacy, which "involves the acceptance of a succession of events without direct evidence that this course of events will happen" [15]. Once again, in lieu of well-founded logical thinking, Erdogan demonstrates his entrenched preference for passionate exaggeration of data, bellicose reactions and an apparently insatiable appetite for threats and intimidation on a massive scale.

\section{CONCLUSIONS}

The analysis above completes our survey of the mostly intentional, but also unintentional - because of passion, clumsiness or superficiality - employment of fallacies by Recep Tayyip Erdogan and his political associates. One main conclusion 
touches upon the emerging political culture of the current Turkish elite. Traditionally, this political culture was marked primarily by narcissism, aggressiveness, and megalomania, but also contained pessimism, self-doubts and insecurity [13. P. 301-317]. What Erdogan's "charismatic" personality and authoritarian operational code seem to have contributed to is the strengthening and deepening of the first triad. Therefore, serious questions have arisen and require urgent answers as to the suspected unreliability of this leader, the consequent fears about Turkey's political and geopolitical objectives, and the best international responses to such unbounded ambitions.

\section{REFERENCES}

[1] Bahceli's Delirium: Cyprus Is Turkish and Will Remain Turkish. Sigmalive.com. 11.06.2018. Available from: http://www.sigmalive.com/news/kypriako/513481/paralirima-mpaxtselii-kypros-einai-tourkiki-am... Accessed: 10.06.2018.

[2] Council of the EU, European Council Conclusions on the Western Balkans and Actions by Turkey in the Eastern Mediterranean and the Aegean Sea, March 22, 2018. Press Release 164/18.

[3] Davutoglu A. Strategic Depth: Turkey's International Position. Athens: Piotita Publications; 2010 (In Greek).

[4] "Delirium" by Deztiji: The Turkish Flag Will Fly Back in Athens". Available from: http://onalert.gr/paralhrhma-destidzi-tourkikh-shmaia-kymatisei-3ana-a8hna/63715. Accessed: 10.06.2018.

[5] Erdogan Advisor Says Greece "Like a Fly Picking a Fight with a Giant". Ekathimerini.com. 14.02.2018. Available from: http://www.ekathimerini.com/225825/article/ekathimerini/news/ erdogan-advisor-says-greece-like-a-fly-picking-a-fight-with-a-giant. Accessed: 10.06.2018.

[6] Fallacies. Texas State University's Dept. of Philosophy. Available from: http://www.txstate.edu/ philosophy/resources/fallacy-definitions. Accessed: 10.06.2018.

[7] Kappa Research, shown by Alpha TV. Athens; 21.03.2018.

[8] Karvounopoulos P. "We Will Take the Life of Others for the Great Turkey". www.militaire.gr. 24.03.2018. Available from: http://www.militaire.gr. Accessed: 10.06.2018.

[9] Kostidis M. Erdogan Spoke About the Borders of His Heart. IBNA. 27.10.2016. Available from: http://www.balkaneu.com/erdogan-spoke-borders-heart. Accessed: 10.06.2018.

[10] Majority of Poll Respondents Say Turkey the Biggest Foreign Threat for Greece. Naftemporiki.gr. 29.04.2018. Available from: http://www.naftemporiki.gr/printStory/1345587. Accessed: 10.06.2018.

[11] Melakopides C. How Rational Is President Erdogan's Policy against Cyprus and Greece: a Case Study. Russian International Affairs Council (RIAC). 08.05.2018.

[12] Melakopides C. Russia-Cyprus Relations: A Pragmatic Idealist Perspective. London: Palgrave; 2016: 14-30.

[13] Melakopides C. Turkey's Political Culture as a Necessary Condition for Decoding Its Policies Toward Cyprus, Greece, and the European Union. Journal of Political and Military Sociology. 2006; Vol. 34; 2 (Winter): 301-317.

[14] Turkey Slams Rotterdam Mayor for BBQ Event Near Mosque During Ramadan. Hurriyet Daily News. 7.06.2018. Available from: http://www.hurriyetdailynews.com/turkey-slamsrotterdam-mayor-for-bbq-event-near-mosque-during-ramadan-132931. Accessed: 10.06.2018.

[13] Yetkin M. "Cross vs. Crescent” Again? Seriously? Hurriyet Daily News. 12.06.2018. Available from: http://www.hurriyetdailynews.com/opinion/murat-yetkin/cross-vs-crescent-again-seriously133156. Accessed: 10.06.2018. 
DOI: 10.22363/2313-1438-2018-20-3-376-385

\title{
КРАТКИЕ ЗАМЕЧАНИЯ \\ О МЕТОДИЧЕСКОМ ИСПОЛЬЗОВАНИИ ЛОГИЧЕСКИХ ПРОТИВОРЕЧИЙ ПРЕЗИДЕНТОМ Р.Т. ЭРДОГАНОМ И ЕГО СТОРОННИКАМИ
}

\author{
К. Мелакопидес \\ Университет Кипра \\ СY-1678, Никосия, Республика Кипр, 20537
}

\begin{abstract}
Представленная статья имеет несколько целей. Во-первых, она направлена на исследование современной вызывающей тревогу политики Президента Турции Р.Т. Эрдогана и его соратников в отношении Греции и Республики Кипр. Автор утверждает, что данная политика характеризуется агрессивностью и воинственностью, что является парадигмой более широких геополитических амбиций Турции. Во-вторых, предпринимается попытка объяснить вероятные политические намерения и геополитические амбиции Р.Т. Эрдогана с помощью ряда объяснительных гипотез, обосновывающих их «непонятный» характер. В-третьих, статья имеет цель определить основные методы и средства, используемые при принятии внешнеполитических решений политическим режимом Президента Р.Т. Эрдогана. Автор полагает, что внешнеполитическая риторика Президента P.T. Эрдогана и его окружения в отношении Греции и Республики Кипр включает умелое использование логических противоречий, которые являются неисследованными в актуальной библиографии, посвященной Р.Т. Эрдогану.
\end{abstract}

Ключевые слова: Р.Т. Эрдоган, Турция, внешняя политика, Республика Кипр, геополитика, политический нарратив

\section{Сведения об авторе:}

Костас Мелакопидес - $\mathrm{PhD}$ по политологии, ассоциированный профессор факультета социальных и политических наук Университета Кипра (Республика Кипр) (e-mail: comel@ucy.ac.cy).

Information about the author:

Costas Melakopides - PhD, Associate Professor (ret.) of the Department of Social and Political Sciences, University of Cyprus (Republic of Cyprus) (e-mail: comel@ucy.ac.cy).

Статья поступила в редакцию 20.06.2018.

Received 20.06.2018.

(C) Мелакопидес К., 2018. 